\title{
New tetradentate Schiff base Cu(II) complexes: synthesis, physicochemical, chromotropism, fluorescence, thermal, and selective catalytic oxidation
}

\author{
Kifah S. M. Salih ${ }^{1}$ (D) $\cdot$ Amjad M. Shraim $^{1}$ (I) $\cdot$ Soaad R. Al-Mhini ${ }^{1} \cdot$ Ranim E. Al-Soufi $^{1} \cdot$ Ismail Warad $^{1}$ (D)
}

Received: 22 December 2020 / Accepted: 4 February 2021 / Published online: 22 February 2021

(C) The Author(s) 2021

\begin{abstract}
Three neutral $\mathrm{Cu}(\mathrm{II}) / \eta^{4}$-NNNO Schiff base complexes (1-3) were prepared from the (E)-4-nitro-2-(((2-(piperazin-1yl)ethyl)imino)methyl)phenol, tetradentate Schiff base (SB) ligand, and the corresponding copper(II) salts. The new SB and its complexes were fully characterized by CHN-EA, standard spectroscopic, thermal, and fluorescence analyses. The formation of the complexes was monitored by EDX, FT-IR, and UV-Vis. The chromotropism studies of the complexes reflected remarkable findings, in which bathochromic solvato- and thermochromism shifts were detected. The turn-off-on halochromism phenomena were observed in the acidic and basic medium. On the other hand, the fluorescence of the free SB ligand was turned off via complexation to the $\mathrm{Cu}(\mathrm{II})$ center. In the presence of $\mathrm{H}_{2} \mathrm{O}_{2}$ as green oxidant and under mild oxidation catalytic condition, the three complexes successfully catalyzed the formation benzaldehyde from benzyl alcohol.
\end{abstract}

Keywords $\mathrm{Cu}(\mathrm{II})$ complexes $\cdot$ Schiff base $\cdot$ Fluorescence $\cdot$ Chromotropism $\cdot$ Catalytic oxidation

\section{Introduction}

Schiff base (SB) group is a valuable subunit $\left(\mathrm{R}^{1} \mathrm{R}^{2} \mathrm{C}=\mathrm{N} \mathrm{R}^{3}\right)$ present in a wide spectrum of compounds. These compounds are accessible from condensation of amines with aldehydes or ketones under conventional or microwave heating. Since the first reported procedure by Schiff [1] in 1864, tremendous efforts have been paid to synthesize a diversity of molecules with this functional feature. The structural variation of SBcontaining compounds allowed their utilization in many applications including nonlinear optical materials, optic data storage, anticancer agents, anticorrosive materials, and coordination chemistry [2-5]. The chelation properties of SB ligands towards coordination to transition metals can be empowered by introducing electron-donating atom such as oxygen, nitrogen, sulfur, and phosphorus to SB scaffold, delivering very stable complexes.

Ismail Warad

ismail.warad@qu.edu.qa

1 Department of Chemistry and Earth Sciences, College of Arts and Sciences, Qatar University, P.O. Box 2713, Doha, Qatar
The presence of salicyl moiety attached to SB derivatives could demonstrate exceptional photo- and thermochromism properties in different physical state. These attributes are typically generated from proton transfer from the o-hydroxyaryl moiety to the attached azomethine (imine) functional group [6-8]. Depending on the electronic conditions of substituents, the o-hydroxyaryl SB-containing compounds could exist in the keto form, enol form, keto/enol mixtures, or rarely in a zwitterionic form [9-13].

Numerous copper (II) complexes bearing SB functional groups have been synthesized, characterized, and served efficiently in several organic transformations, particularly in oxidation reactions [14-16]. Selective oxidation of alcohols to aldehydes and ketones over transition metal catalysts has been intensively pursued under a number of heterogeneous and homogeneous conditions, since carbonyl derivatives are considered significant intermediates employed in the production of dyes, flavors, fragrances, and medicines [17-20]. Many sustainable catalytic transformations have been accomplished in the presence of molecular oxygen and hydrogen peroxide as oxidants. However, peroxide is broadly used for possessing greater oxidation potential than oxygen $[17,21,22]$.

Thus, there is a need to synthesize novel multi-dentate SB ligands and their metal complexes for more potent biological 
and catalytical applications. In this work, we report the synthesis and full characterization of $(E)$-4-nitro2-(((2-(piperazin-1-yl)ethyl)imino)methyl)-phenol as a SBfunctionalized compound from condensation of 2-hydroxy5-nitrobenzaldehyde and 2-(1-piperazinyl)ethylamine. Since the synthesized SB symbolizes an appropriate tetradentate ligand via three $\mathrm{N}$ and one $\mathrm{O}$ atoms, we have performed the coordination experiment with three copper(II) salts through subsequent deprotonation/coordination process in the absence of base. The solvatochromic, halochromtic, thermochromic, florescence, and thermal behaviors were investigated. Moreover, selective catalytic oxidation of benzyl alcohol to benzyl aldehyde was evaluated using the desired complexes in the presence of hydrogen peroxide as a green oxidant.

\section{Experimental}

\subsection{Materials and measurements}

Fine chemicals were of reagent grade and solvents were of analytical grade; all were harnessed directly without any purification process. Copper(II) bromide, 2-hydroxy-5nitrobenzaldehyde, and 2-(1-piperazinyl)ethylamine were received from Sigma-Aldrich. Copper(II) nitrate trihydrate and copper(II) chloride were procured from Acros Organics. FTIR transmission spectra were recorded in solid state through Bruker ALPHA FT-IR spectrometer in the range of 400-4000 $\mathrm{cm}^{-1}$. NMR spectra were recorded on JOEL $600 \mathrm{MHz}$ spectrometer with internal reference to the residual solvent signal, $\mathrm{CHCl}_{3}: \delta=7.24$ ppm for ${ }^{1} \mathrm{H}-\mathrm{NMR}$ and $\delta=77.00 \mathrm{ppm}$ for ${ }^{13} \mathrm{C}$ NMR. The UV-Vis measurements were accomplished in neat water using Agilent 8453 single-beam spectrophotometer. Relative fluorescence was measured using Shimadzu Spectrofluorophotometer RF-6000. Mass spectra were collected employing Shimadzu GC-MS QP2010. The CHN analysis was performed using Thermo Scientific ${ }^{\mathrm{TM}}$ FLASH $^{\mathrm{TM}}$ 2000 Organic Elemental Analyzer. The magnetic behavior was demonstrated using Magnetic Susceptibility Balance MK1 from Sherwood Scientific Ltd. TGA and DSC analyses were performed using PerkinElmer TGA 4000 and PerkinElmer DSC 4000, respectively. Quanta 200 Environmental Scanning Electron Microscope with EDAXEDSSEM was used to record images and chemical composition.

\subsection{Synthesis}

\subsubsection{Synthesis of SB ligand}

A solution of $334 \mathrm{mg}(2.2 \mathrm{mmol})$ of 2-hydroxy-5nitrobenzaldehyde dissolved in a minimum amount of THF $(\sim 10 \mathrm{~mL})$ was added to THF solution $(5 \mathrm{~mL})$ of $270 \mu \mathrm{L}(2.1$ mmol) of 2-(1-piperazinyl)ethylamine at room temperature. The mixture was subjected to vigorous stirring until the color turned to light brown. After $2 \mathrm{~h}$, a yellow precipitate was formed, filtered, and washed well with $20 \mathrm{~mL}$ of $\mathrm{n}$-hexane and $40 \mathrm{~mL}$ of distilled water and then dried. The final product ( $(E)$-4-nitro-2-(((2-(piperazin-1-yl)ethyl)imino) $\mathrm{m}$ ethyl)phenol) was obtained in $84 \%$ yield, having a $\mathrm{mp}=81$ ${ }^{\circ} \mathrm{C}$. Anal. Calcd. for $\mathrm{C}_{13} \mathrm{H}_{18} \mathrm{~N}_{4} \mathrm{O}_{3}$ : C, 56.10; H, 6.52; N, 20.13. Found: C, 56.06; H, 6.41; N, 20.05. $\left[\mathrm{M}^{+}\right] \mathrm{m} / z=278.2(278.14$, theoretical). FT-IR: $3240\left(v_{\mathrm{C}-\mathrm{OH}}\right), 3110\left(v_{\mathrm{C}-\mathrm{H}-\mathrm{Ph}}\right), 2910\left(v_{\mathrm{C}-}\right.$ $\left.{ }_{\mathrm{H}}\right), 1680\left(v_{\mathrm{C}=\mathrm{N}}\right) \mathrm{cm}^{-1}$. UV/Vis. Abs. in $\mathrm{MeOH}, \lambda_{\max }=231$, 315 , and $398 \mathrm{~nm} .{ }^{1} \mathrm{H}-\mathrm{NMR}\left(600 \mathrm{MHz}, \mathrm{CDCl}_{3}\right): \delta=$ at $1.23(\mathrm{~s}$, $1 \mathrm{H}, \mathrm{N}-\mathrm{H}), 2.50$ (br, $4 \mathrm{H}, 2 \times \mathrm{CH}_{2}$-pip), 2.72 (t, $J=6.8 \mathrm{~Hz}, 2 \mathrm{H}$, $\left.\mathrm{CH}_{2} \mathrm{~N}\right), 2.88\left(\mathrm{t}, J=4.7 \mathrm{~Hz}, 4 \mathrm{H}, 2 \times \mathrm{CH}_{2}\right.$-pipN), 3.67 (t, $J=6.8$ $\left.\mathrm{Hz}, 2 \mathrm{H}, \mathrm{C}=\mathrm{NCH}_{2}\right), 6.84(\mathrm{~d}, J=8.5 \mathrm{~Hz}, 1 \mathrm{H}, \mathrm{Ph}), 7.19(\mathrm{dd}, J=$ 9.0, $2.4 \mathrm{~Hz}, 1 \mathrm{H}, \mathrm{Ph}), 7.41(\mathrm{~s}, 1 \mathrm{H}, \mathrm{Ph}), 7.42(\mathrm{~s}, 1 \mathrm{H}, \mathrm{HC}=\mathrm{N})$, 16.33 (br, $1 \mathrm{H}, \mathrm{OH}) \mathrm{ppm} .{ }^{13} \mathrm{C}-\mathrm{NMR}\left(600 \mathrm{MHz}, \mathrm{CDCl}_{3}\right): \delta=$ $45.14\left(2 \mathrm{C}, 2 \times\left(\mathrm{CH}_{2}\right)_{2} \mathrm{NH}\right), 47.04\left(\mathrm{CH}_{2} \mathrm{~N}_{\text {pip }}\right), 54.81(2 \mathrm{C}, 2 \times$ $\left.\left(\mathrm{CH}_{2}\right)_{2} \mathrm{~N}\right), 58.86\left(=\mathrm{NCH}_{2}\right), 119.76\left(\mathrm{C}_{\mathrm{Ar}}\right), 120.61\left(\mathrm{C}_{\mathrm{Ar}}\right)$, $121.31\left(\mathrm{C}_{\mathrm{Ar}}\right), 127.47\left(\mathrm{C}_{\mathrm{Ar}}\right), 132.52\left(\mathrm{C}_{\mathrm{Ar}}\right), 163.27\left(\mathrm{C}_{\mathrm{Ar}}\right)$, $171.12(\mathrm{C}=\mathrm{N}) \mathrm{ppm}$.

\subsubsection{Synthesis of $\mathrm{Cu}(\mathrm{II})$ complexes}

A solution $3.60 \mathrm{mmol}$ of copper(II) salt dissolved in $10-\mathrm{mL}$ THF was added to a solution of $3.60 \mathrm{mmol}(1.00 \mathrm{~g})$ of NNNOtetradentate ligand in $10 \mathrm{~mL}$ of hot THF. The color of the reaction mixture was turned to green directly within a minute before it started to precipitate. Stirring at room temperature was continued for $10 \mathrm{~min}$ to ensure completeness of the reaction. The desired complex was then filtrated and washed with diethyl ether and n-hexane and then dried under vacuum.

Complex $1 \mathrm{~A}$ mass of $0.48 \mathrm{~g}$ of $\mathrm{CuCl}_{2}$ afforded green watersoluble powder of complex 1 with $80 \%$ yield, $\mathrm{mp}=198{ }^{\circ} \mathrm{C}$. Anal. Calcd. for $\mathrm{C}_{13} \mathrm{H}_{19} \mathrm{ClCuN}_{4} \mathrm{O}_{4}$ : C, 39.60; H, 4.86; N, $14.21 \%$. Found: C, 39.35; H, 4.74; N, 14.09\%. FT-IR: 3455 $\left(v_{\mathrm{H} 2 \mathrm{O}}\right), 3375\left(v_{\mathrm{H}-\mathrm{N}}\right), 3122\left(v_{\mathrm{C}-\mathrm{H}}\right.$ of $\left.\mathrm{ph}\right), 2895\left(v_{\mathrm{C}-\mathrm{H}}\right), 1620$ $\left(v_{\mathrm{N}=\mathrm{C}}\right), 1520,1442,1378\left(v_{\mathrm{NO} 2}\right), 1180\left(v_{\mathrm{N}-\mathrm{C}}\right), 610,540$, and $450\left(v_{\mathrm{Cu}-\mathrm{N}}\right)$ [23]. UV-Vis in water: $\lambda_{\max } \mathrm{nm}\left(\varepsilon_{\max }\right.$ in $\mathrm{M}^{-1}$ $\left.\mathrm{cm}^{-1}\right): 255\left(5 \times 10^{4}\right), 375\left(2.5 \times 10^{4}\right), 670(160)$.

Complex 2 A mass of $0.80 \mathrm{~g}$ of $\mathrm{CuBr}_{2}$ gave green watersoluble powder of complex 2 with $84 \%$ yield, $\mathrm{mp}=183{ }^{\circ} \mathrm{C}$. Anal. Calcd. for $\mathrm{C}_{13} \mathrm{H}_{19} \mathrm{BrCuN}_{4} \mathrm{O}_{4}$ : C, 35.59; H, 4.36; N, 12.77\%. Found: C, 35.44; H, 4.28; N, 12.59\%. FT-IR: 3440 $\left(v_{\mathrm{H} 2 \mathrm{O}}\right), 3355\left(v_{\mathrm{H}-\mathrm{N}}\right), 3116\left(v_{\mathrm{C}-\mathrm{H}-\mathrm{Ph}}\right), 2874\left(v_{\mathrm{C}-\mathrm{H}}\right), 1610$ $\left(v_{\mathrm{N}=\mathrm{C}}\right), 1530,1452,1376\left(v_{\mathrm{NO} 2}\right), 1170\left(v_{\mathrm{N}-\mathrm{C}}\right), 612,542$, and $453\left(v_{\mathrm{Cu}-\mathrm{N}}\right)$. UV-Vis in water: $\lambda_{\max } \mathrm{nm}\left(\varepsilon_{\max }\right.$ in $\mathrm{M}^{-1}$ $\left.\mathrm{cm}^{-1}\right): 240\left(3.0 \times 10^{4}\right), 350\left(2.2 \times 10^{4}\right), 650(120)$.

Complex $3 \mathrm{~A}$ mass of $0.87 \mathrm{~g}$ of $\mathrm{Cu}\left(\mathrm{NO}_{3}\right)_{2} 3 \mathrm{H}_{2} \mathrm{O}$ yielded darkgreen water-soluble powder of complex 3 with $65 \%$ yield, mp

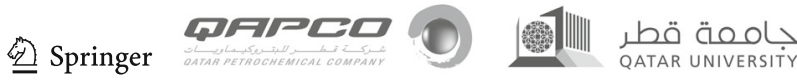


$=235^{\circ} \mathrm{C}$. Anal. Calcd. for $\mathrm{C}_{13} \mathrm{H}_{19} \mathrm{CuN}_{5} \mathrm{O}_{7}: \mathrm{C}, 37.10 ; \mathrm{H}, 4.55$; N, 16.64. Found C, 37.38; H, 4.68; N, 16.36\%, FT-IR: 3450 $\left(v_{\mathrm{H} 2 \mathrm{O}}\right), 3355\left(v_{\mathrm{H}-\mathrm{N}}\right), 3118\left(v_{\mathrm{C}-\mathrm{H}}\right.$ of $\left.\mathrm{ph}\right), 2884\left(v_{\mathrm{C}-\mathrm{H}}\right), 1630$ $\left(v_{\mathrm{N}=\mathrm{C}}\right), 1525,1443,1367\left(v_{\mathrm{NO} 2}\right), 1168\left(v_{\mathrm{N}-\mathrm{C}}\right), 615,542,458$ $\left(v_{\mathrm{Cu}-\mathrm{N}}\right)$. UV-Vis in water: $\lambda_{\max } \mathrm{nm}\left(\varepsilon_{\max }\right.$ in $\left.\mathrm{M}^{-1} \mathrm{~cm}^{-1}\right): 265$ $\left(1.0 \times 10^{4}\right), 370\left(7.2 \times 10^{3}\right), 615(80)$.

\subsection{Catalytic oxidation of alcohol}

The oxidation of benzyl alcohol was achieved by using hydrogen peroxide in the presence of copper(II) complex as a catalyst. Typically, a mixture of $2.5 \mathrm{mmol}$ of benzyl alcohol, $5 \mathrm{mmol}$ of $30 \%$ hydrogen peroxide, $1 \mathrm{~mol} \%$ of copper catalyst, and $10 \mathrm{~mL}$ of solvent (see Table 1) was heated at $50{ }^{\circ} \mathrm{C}$ for $24 \mathrm{~h}$ in two-necked round-bottomed flask connected to reflux column. The reaction was monitored by FT-IR focusing on the $\mathrm{C}=\mathrm{O}$ vibration at $\sim 1700 \mathrm{~cm}^{-1}$. When the reaction was finished, the whole mixture was transferred to $100 \mathrm{~mL}$ separatory funnel containing $20 \mathrm{~mL}$ of $\mathrm{CH}_{2} \mathrm{Cl}_{2}$ and water. The organic layer was evaporated and the produced benzaldehyde was confirmed by IR and NMR.

\section{Results and discussion}

\subsection{Synthesis and characterization}

In the condenzation reaction of 2-(1-piperazinyl)ethylamine with 2-hydroxy-5-nitrobenzaldehyde, SB-functionalized ligand, $(E)-4-n i t r o-2-(((2-($ piperazin-1-yl)ethyl)imino)m ethyl)phenol, was afforded in a very good yield within $2 \mathrm{~h}$ at ambient conditions. The presence of different functional groups on the skeleton of the ligand makes it an appropriate tetradentate ligand via three $\mathrm{N}$ and one $\mathrm{O}$ atoms. Hence, in an equimolar ratio with three copper(II) salts $\left(\mathrm{CuCl}_{2}, \mathrm{CuBr}_{2}\right.$, and $\left.\mathrm{Cu}\left(\mathrm{NO}_{3}\right)_{2} 3 \mathrm{H}_{2} \mathrm{O}\right)$, separately, the ligand was coordinated in an NNNO-fashion to the metal center in a consecutive deprotonation/coordination process in the absence of base (Scheme1). The ligand and the complexes have reflected good solubility in common polar solvents such as $\mathrm{MeOH}$, DMF, DMSO, and water.

The ${ }^{1} \mathrm{H}-\mathrm{NMR}$ spectrum of the ligand in $\mathrm{CDCl}_{3}$ revealed the corresponding peaks for the expected structure (Fig. 1a). The $\mathrm{N}-\mathrm{H}$ of piperazinyl moiety was found as a broad peak at 1.23 ppm, while the two methylenes of piperazinyl ring were detected at $2.50\left(\right.$ br, $\left.2 \times \mathrm{CH}_{2} \mathrm{NH}\right)$ and $2.88\left(\mathrm{t}, 2 \times \mathrm{CH}_{2} \mathrm{~N}\right) \mathrm{ppm}$. The two aliphatic methylenes were observed as triplet signal at $2.72\left(\mathrm{CH}_{2} \mathrm{~N}\right)$ and $3.67\left(\mathrm{C}=\mathrm{NCH}_{2}\right) \mathrm{ppm}$. The three aromatic protons were seen as expected at $6.84(\mathrm{~d}), 7.19(\mathrm{dd})$, and 7.41(s) ppm. The singlet peak at $7.42 \mathrm{ppm}$ was assigned to the proton of imine group. Remarkably, the phenolic proton was extremely deshielded to appear as a broad peak at 16.33 ppm. The ${ }^{13} \mathrm{C}$-NMR spectrum, on the other hand, displayed all aliphatic, aromatic, and iminic carbon peaks at the expected range of chemical shifts, as illustrated in Fig. 1b.

The recorded FT-IR of the synthesized ligand and complex $\mathbf{1}$ are displayed in Fig. 2. The formation of SB functional group was confirmed via the disappearance of the two weak absorption bands at 3361 and $3275 \mathrm{~cm}^{-1}$ from piperazinylethylamine moiety. However, the evanescence of $\mathrm{O}-\mathrm{H}$ band

Table 1 Catalytic oxidation of benzyl alcohol

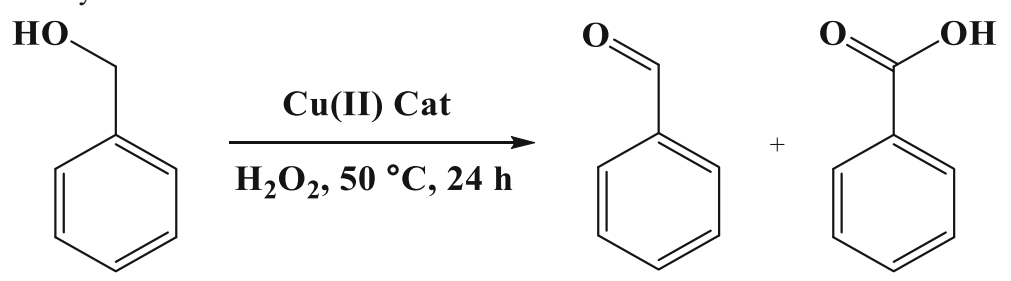

\begin{tabular}{cccccc}
\hline Entry & Complex & Solvent & Conv. $\%$ & Benzaldehyde\% $^{\mathbf{e}}$ & ${\text { Benzoic acid } \%^{\mathbf{e}}}^{\mathbf{e}^{2}}$ \\
\hline 1 & $\mathbf{1}$ & $\mathrm{H}_{2} \mathrm{O}$ & $>99$ & 99 & nd \\
2 & $\mathbf{2}$ & $\mathrm{H}_{2} \mathrm{O}$ & 90 & 88 & nd \\
3 & $\mathbf{3}$ & $\mathrm{H}_{2} \mathrm{O}$ & 45 & 40 & nd \\
$4^{\mathrm{a}}$ & $\mathbf{1}$ & $\mathrm{H}_{2} \mathrm{O}$ & $>99$ & 70 & 28 \\
$5^{\mathrm{b}}$ & $\mathbf{1}$ & $\mathrm{H}_{2} \mathrm{O}$ & $>99$ & 40 & 53 \\
6 & $\mathbf{1}$ & $\mathrm{THF}$ & $>95$ & 90 & nd \\
7 & $\mathbf{1}$ & $\mathrm{CH}_{3} \mathrm{CN}$ & $>93$ & 87 & nd \\
8 & $\mathbf{1}$ & $\mathrm{DMSO}$ & $>99$ & 96 & nd \\
$9^{\mathrm{c}}$ & - & $\mathrm{H}_{2} \mathrm{O}$ & 0 & 0 & nd \\
$10^{\mathrm{d}}$ & $\mathbf{1}$ & $\mathrm{H}_{2} \mathrm{O}$ & 3 & $\leq 1$ & nd \\
\hline
\end{tabular}

Conditions: $2.5 \mathrm{mmol}$ of $\mathrm{BnOH}, 5 \mathrm{mmol}$ of $30 \% \mathrm{H}_{2} \mathrm{O}_{2}, 1 \mathrm{~mol} \%$ of copper catalyst, $10 \mathrm{~mL}$ of solvent, $50{ }^{\circ} \mathrm{C}$ for $24 \mathrm{~h}$. nd $=$ not detected

${ }^{\mathrm{a}} 70{ }^{\circ} \mathrm{C},{ }^{\mathrm{b}} 48 \mathrm{~h},{ }^{\mathrm{c}}$ no catalyst, ${ }^{\mathrm{d}}$ no $\mathrm{H}_{2} \mathrm{O}_{2}$ and ${ }^{\mathrm{e}}$ isolated yield 
Fig. $1{ }^{1} \mathrm{H}-\mathrm{NMR}$ (a) and ${ }^{13} \mathrm{C}$ NMR (b) of the SBfunctionalized ligand in $\mathrm{CDCl}_{3}$
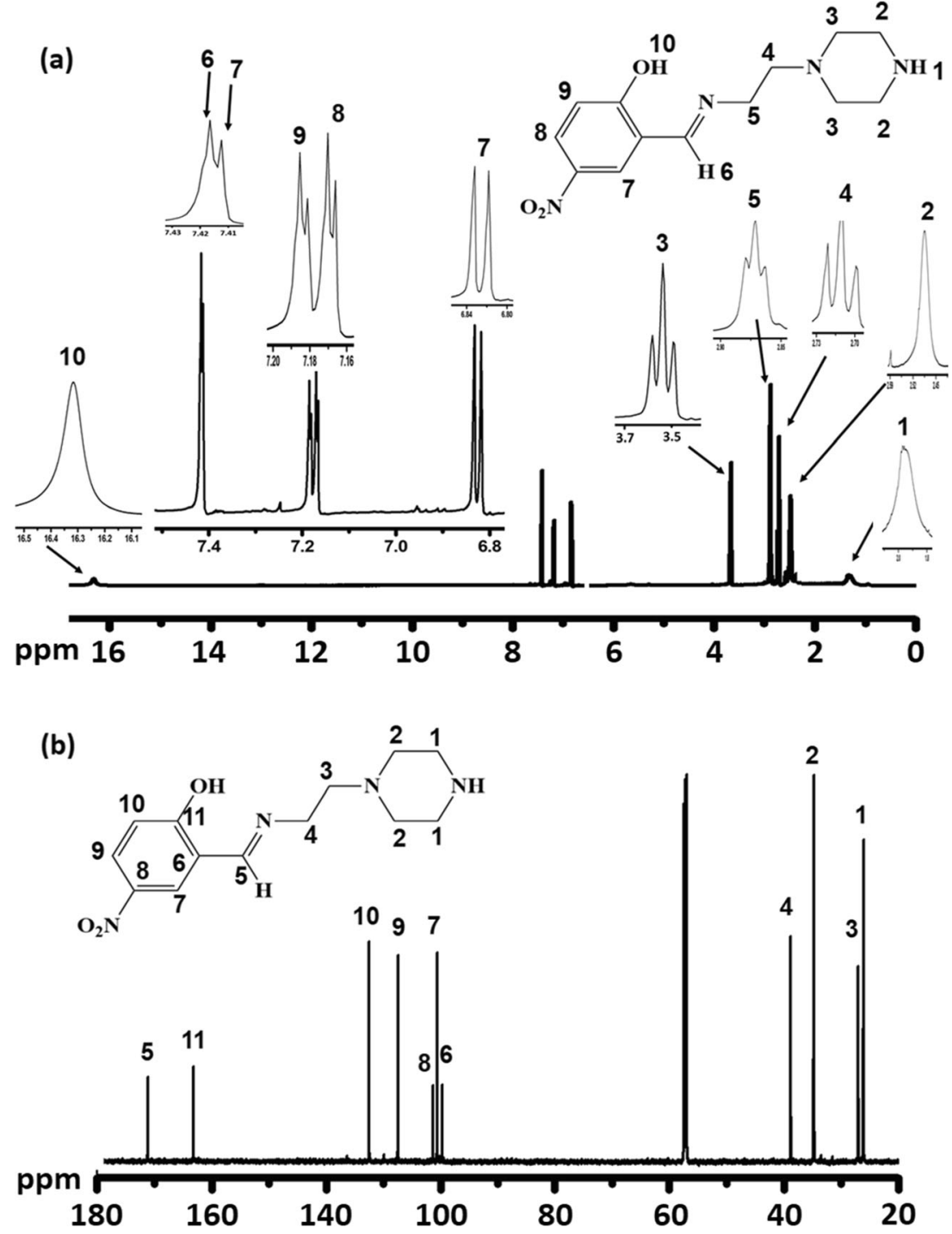

in the area of $3100-3500 \mathrm{~cm}^{-1}$ in both starting material and ligand can be attributed to the strong intramolecular hydrogen bonding with $\mathrm{C}-\mathrm{OH}$ and $\mathrm{C}=\mathrm{N}[24,25]$. The typical aliphatic and aromatic $\mathrm{C}-\mathrm{H}$ stretching vibrations were appeared in the range of 3071 to $2840 \mathrm{~cm}^{-1}$. These $\mathrm{C}-\mathrm{H}$ bands were displayed as well in the complex; the coordination of the ligand to copper metal center was clearly confirmed via the shifting of $\mathrm{C}=\mathrm{N}$ stretching band from 1655 to $1624 \mathrm{~cm}^{-1}$. Since the electron pair of nitrogen is involved in coordination bond, the distribution of the electron density to copper metal center and the subsequent polarization led to electron depopulation of the $\mathrm{C}=\mathrm{N}$ group, resulting a slightly lower shift. Additionally, a broad stretching vibration at $3405 \mathrm{~cm}^{-1}$ strongly indicated the coordination of a water molecule to the complex. Further absorptions were present in the spectrum for other functional groups, such as $\mathrm{C}=\mathrm{C}, \mathrm{C}-\mathrm{C}, \mathrm{C}-\mathrm{N}$, and $\mathrm{C}-\mathrm{O}$.

Elemental analyses of SB-functionalized ligand and its complexes 1-3 were in a good agreement with the composition of the expected molecular formula and proposed structures, respectively (Scheme 1). The GC-MS for the ligand and one of the copper complexes, complex 1, reflected an excellent fragment consistent with their expected molecular formulas. Furthermore, the ligand and complex 1 were analyzed via EDX. The tetradentate ligand reflected the presence of $\mathrm{C}, \mathrm{N}$, and $\mathrm{O}$ atoms, while the complex additionally displayed $\mathrm{Cl}$ and three typical signals of $\mathrm{Cu}$ atoms, indicating the formation of the complex (Fig. 3a, b). Scanning electron microscopy (SEM) was employed to obtain the morphology of the ligand and its complex. Irregular rod-shaped nanostructure was observed for the ligand, whereas, a block-shaped made of fluffy nano-sheets (larger than $10 \mu \mathrm{m}$ ) is grown by the $\mathrm{Cu}$ (II) complex (Fig. 3c, d). Surface properties based on the BET technique with nitrogen physisorption at -196.15 ${ }^{\circ} \mathrm{C}(77 \mathrm{~K})$ as a carrier gas were evaluated to be 70 and 45 $\mathrm{m}^{2} / \mathrm{g}$ for the ligand and complex, respectively. 
Fig. 2 FT-IR of 2-(1piperazinyl)ethylamine (a), 2hydroxy-5-nitrobenzaldehyde (b), ligand (c), complex 1 (d)

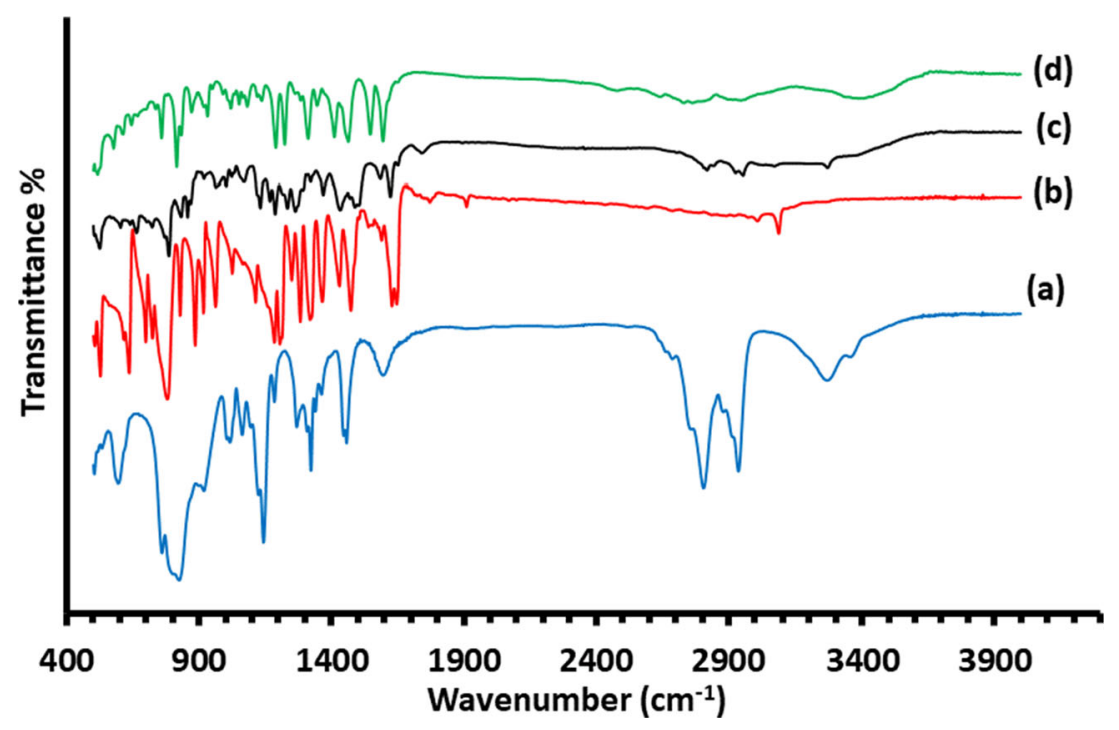

\subsection{Electronic absorption and fluorescence spectra}

The experimental electronic absorption spectra of the starting materials, synthesized ligand, and complex 1 were acquired from neat methanolic solution in the spectral range of 200$800 \mathrm{~nm}$ at ambient conditions. The free amine was characterized with band at $\lambda_{\max }=223 \mathrm{~nm}$ resulting from n- $\sigma^{*}$ electron transition, while two bands in the UV area were displayed by the 2-hydroxy-5-nitrobenzaldehyde derivative at $\lambda_{\max }=240$ and $310 \mathrm{~nm}$ attributed to $\mathrm{n}-\sigma^{*}$ and $\pi-\pi^{*}$ electron transfer, respectively (Fig. 4a, b). Three broad bands with maximum absorption at 231, 315, and 398 were revealed by the ligand, these absorptions could be ascribed to $n-\sigma^{*}, \pi-\pi^{*}$, and $n-\pi^{*}$ [26,27]; the last electron transition indicates the formation of the ligand from the condensation reaction (Fig. 4c). Complex 1 has exhibited two strong absorptions at $\lambda_{\max }=252$ and 357 $\mathrm{nm}$, the first peak was assigned to $\mathrm{n}-\sigma^{*}$ with distinctive bathochromic shift from the value observed by the ligand. Whereas, the second wide peak could be resonated to ligand-to-metal charge transfer (LMCT) (Fig. 4d) [28]. This spectral pattern indicates the coordination of the tertradentate ligand to copper metal center. Furthermore, at a high level of concentration (as the molar absorptivity is very low), the complex has revealed the d-d absorption band in the visible region, at $\lambda_{\max }=675 \mathrm{~nm}$ (Fig. 4e), which is in consistence with similar reported complex systems [5-10].

The emission spectra for the ligand at $360 \mathrm{~nm}$ at different concentrations $\left(0-2.9 \times 10^{-4} \mathrm{M}\right)$ are presented in Fig. 5a. As obvious from the spectra, the emission intensity of the ligand at about $475 \mathrm{~nm}$ increased until a concentration of $5.8 \times 10^{-5}$ $\mathrm{M}$ then decreased afterwards. The ligand's emission intensity vs. its concentration is plotted in Fig. 5b; the ligand's optimum intensity occurred at a concentration of $5.8 \times 10^{-5} \mathrm{M}$. The decrease in intensity at high concentrations (e.g., $>5.8 \times$ $10^{-5} \mathrm{M}$ ) can be explained by reabsorption of emitted photons by ground-state molecules. The emission spectra for the complex $1\left(0-2.0 \times 10^{-4} \mathrm{M}\right)$ are low and can be neglected compared to the ligand emission at the same concentrations $(5.8 \times$
Scheme 1 Synthesis of SBfunctionalized ligand and it complexes

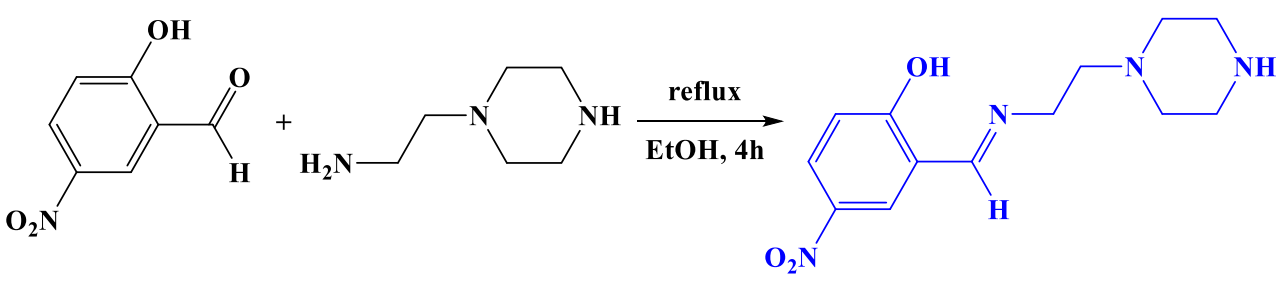

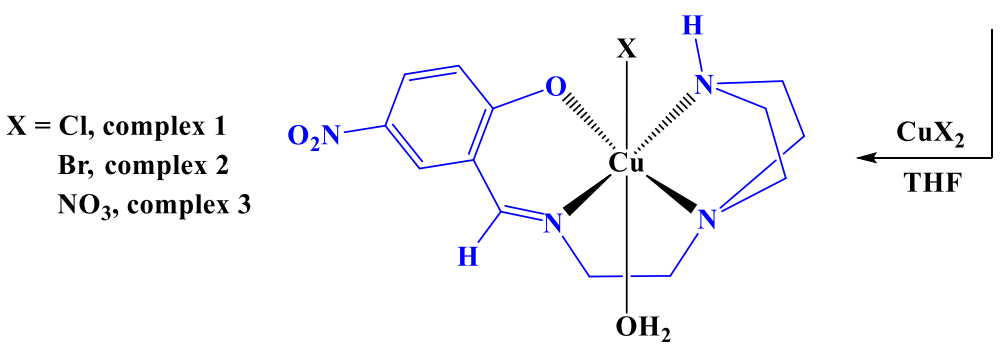



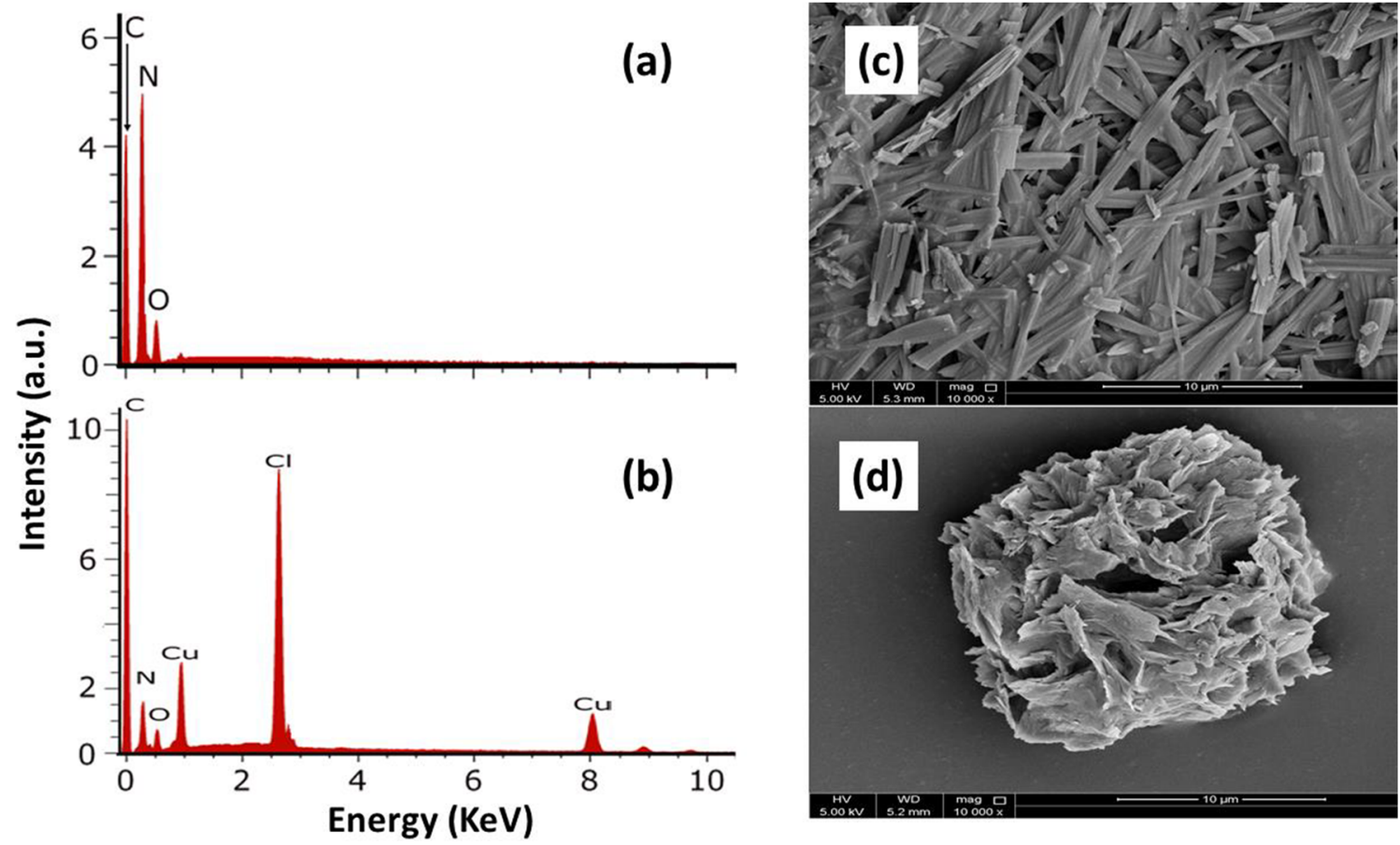

Fig. 3 EDX for ligand (a) and complex 1 (b); SEM images for ligand (c) and complex 1 (d)

$10^{-5} \mathrm{M}$ ) as seen Fig. 4c, which reflects the maximum emission of the free ligand at $5.8 \times 10^{-5} \mathrm{M}$. Meanwhile, a turn-off of the complex's emission intensity occurred at the same concentration. Due to the tetradentate NNNO of the ligand, emission turn-off was recorded upon its coordination to the copper center to form complex 1. Similar observations were reported for the quenching of the fluorescence of certain ligands after complexing with $\mathrm{Cu}$ (II) [29-32]. The reason behind this turn-off phenomenon is unclear but this may be due to the predominance of photo-induced electron transfer (PET) over chelation-enhanced fluorescence (CHEF) [29,30]. Also, this could be due to the alternation of the structure of the ligand upon complexation [33].

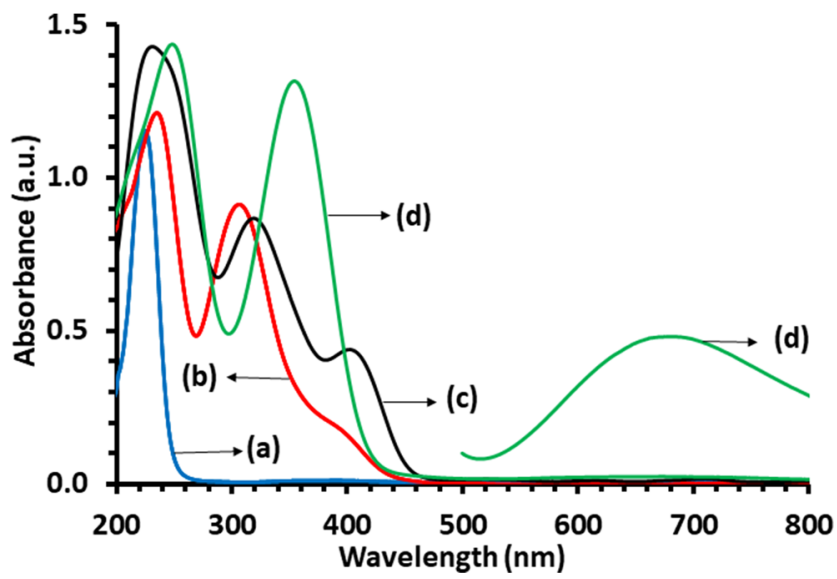

Fig. 4 UV-Vis spectra of 2-(1-piperazinyl)ethylamine (a), 2-hydroxy-5nitrobenzaldehyde (b), ligand (c), complex 1 (d), and complex 1 at concentrated level (e)

\subsection{Job's method, gravimetric analysis, conductivities, and magnetic susceptibility}

Since the prepared complexes did not crystallize in a suitable quality for XRD-crystal measurement, Job's method was employed to get more information about the stoichiometry of the desired complexes. Therefore, titration of the desired $\mathrm{NNNOH}$ ligand with varying concentrations of $\mathrm{Cu}$ (II) in water is presented in Fig. 6a. The Job's plot for NNNO-Cu(II) system (complex 1) is illustrated in Fig. 6b, which reflected the formation of the complex at a 1:1 ratio. Such coordination enabled us to propose a mono-halide octahedral $\mathrm{Cu}$ (II) geometry via coordinated tetradentate $\left(\mathrm{NNNO}^{-}\right) \mathrm{SB}$, as demonstrated in Scheme 1. Thus, to examine the mono-halide structural formula of the complexes, halide quantity in complexes $\mathbf{1}$ and 2 were gravimetrically evaluated using excess amount of $\mathrm{AgNO}_{3}(\mathrm{aq})$ then referenced to $\mathrm{CuCl}_{2} \quad 3 \mathrm{H}_{2} \mathrm{O}$ and $\mathrm{CuBr}_{2}$ $6 \mathrm{H}_{2} \mathrm{O}$ respectively. The gravimetric analysis results showed that complexes $\mathbf{1}$ and $\mathbf{2}$ have half amounts of halide compared to their corresponding starting complexes. Moreover, the resulting product from gravimetric analysis of both complexes $\mathbf{1}$ and $\mathbf{2}$ (Scheme 2) was confirmed by IR and UV-Vis to be complex 3.

The electrolytic conductivity values at $22{ }^{\circ} \mathrm{C}$ in $5 \mathrm{~mL}$ $\left(4 \times 10^{-5} \mathrm{M}\right)$ in distilled water were found to be 352,484 , and $285 \mu \mathrm{S} / \mathrm{cm}$ for complexes $\mathbf{1}, \mathbf{2}$, and $\mathbf{3}$, respectively. However, the initial copper(II) salt $\left(\mathrm{CuCl}_{2}, \mathrm{CuBr}_{2}\right.$, and $\left.\mathrm{Cu}\left(\mathrm{NO}_{3}\right)_{2}\right)$ were found to measure 705,985 , and 589 $\mu \mathrm{S} / \mathrm{cm}$ under identical concentrations and conditions. Since the conductivity of the prepared complexes 
Fig. 5 Emission spectra of the ligand in DMSO at room temp. $\left(\mathrm{C}_{1}=0, \mathrm{C}_{2}=2.9 \times 10^{-6}, \mathrm{C}_{3}=5.8 \times\right.$ $10^{-5}, \mathrm{C}_{4}=1.45 \times 10^{-4}, \mathrm{C}_{5}=2.32$ $\times 10^{-4}, \mathrm{C}_{6}=2.9 \times 10^{-4} \mathrm{M}$ ) at different concentrations (a), ligand optimum emission concentrations (b), and free ligand (turn on) and it's complex 1 (turn off)

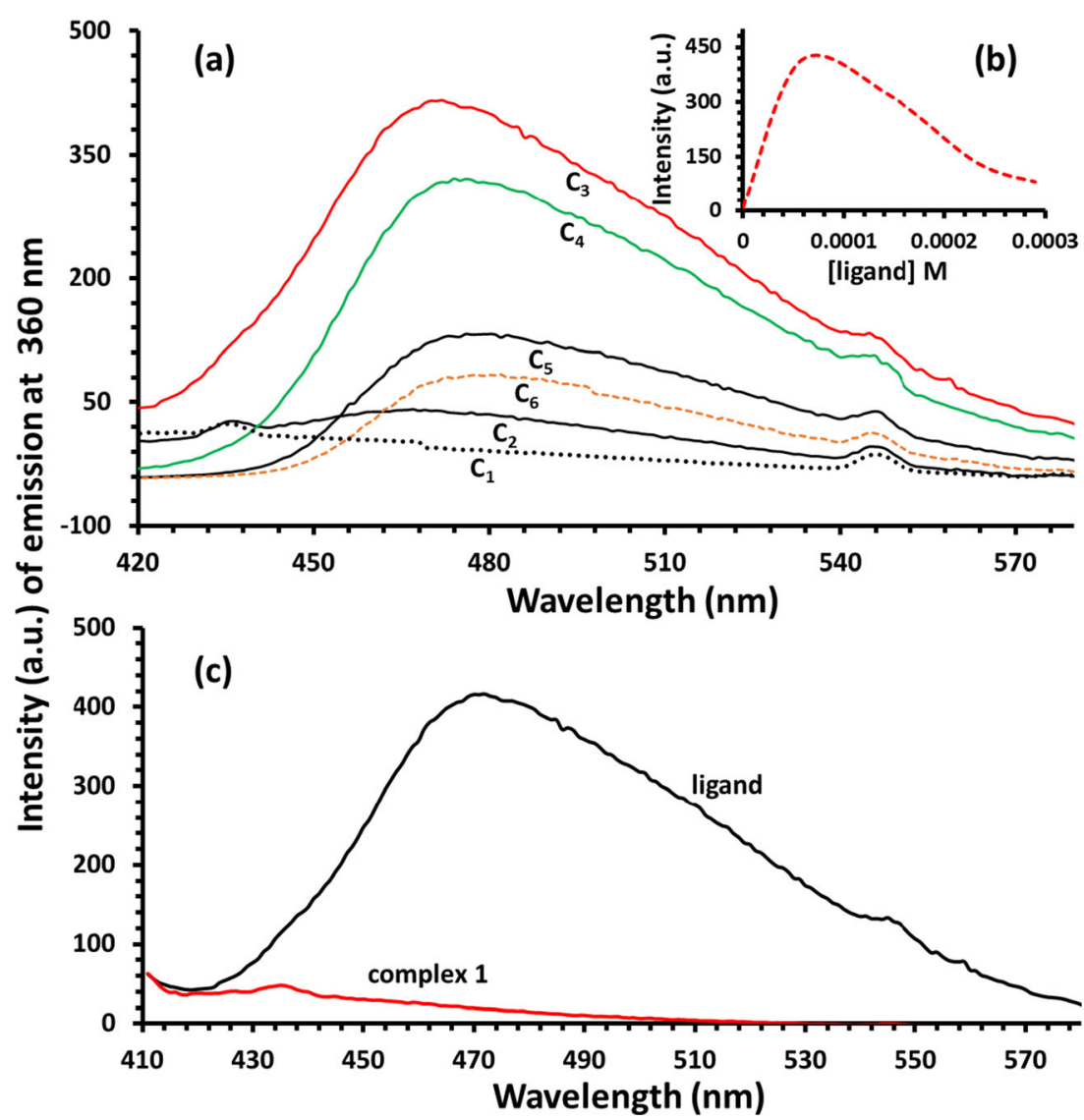

measured about half values of starting salts, the desired complexes are expected to be mono-halides or mononitrate complexes in its nature form. Remarkably, upon increasing the temperature up to $100{ }^{\circ} \mathrm{C}$ for the aqueous solution of complex $\mathbf{1}$, the ionization behavior of the halide was observed to increase, as seen in Fig. 6d.
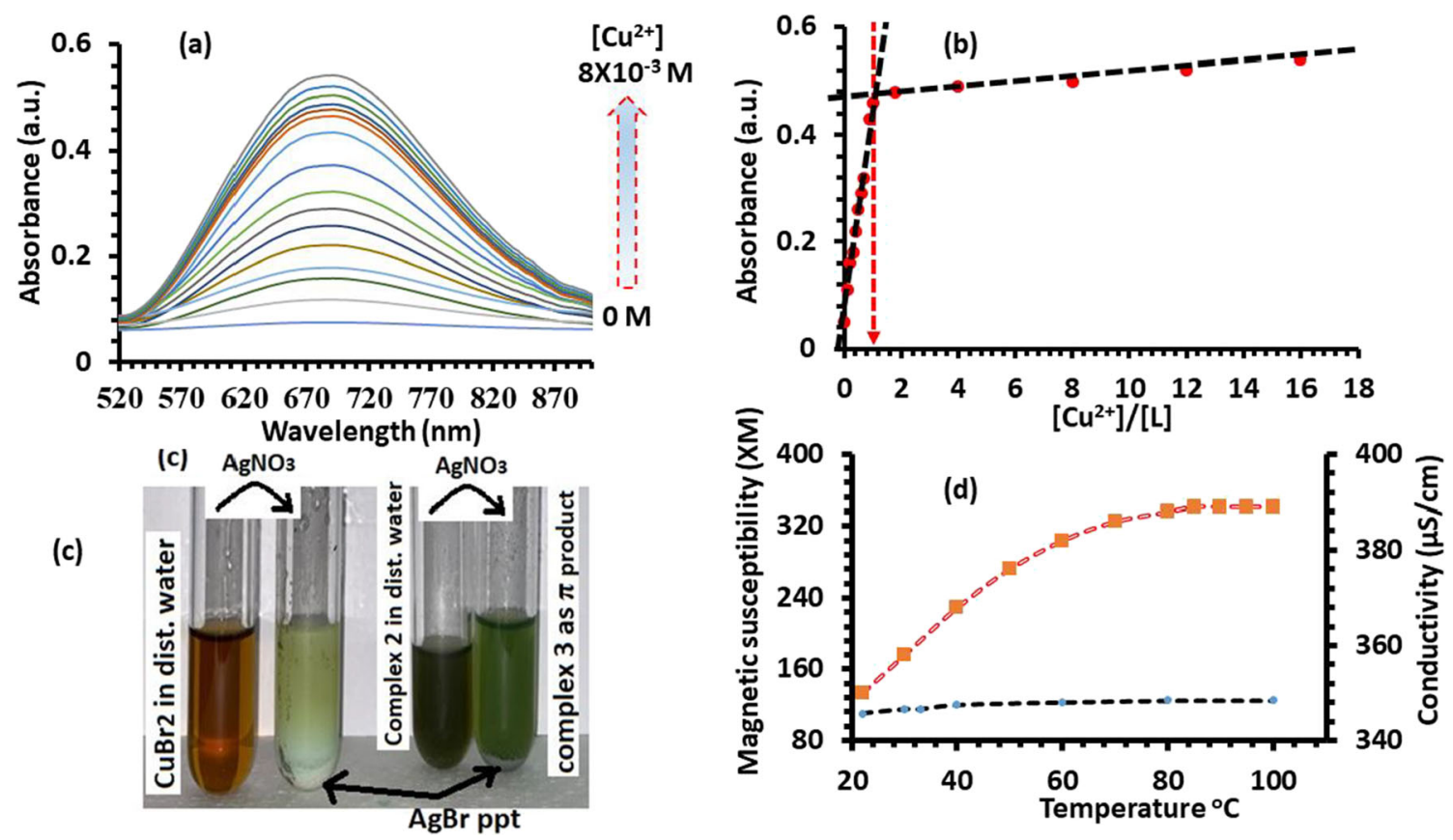

Fig. 6 UV-Vis absorption spectrum for the titration of SB ligand with $\mathrm{Cu}(\mathrm{II})$ at $675 \mathrm{~nm}$ (a); Job's plot for SB-Cu(II) system (b); gravimetric analysis of complex 2 (c); and electrolytic conductivity (I) and magnetic susceptibility (II) of complex 1 (d) 


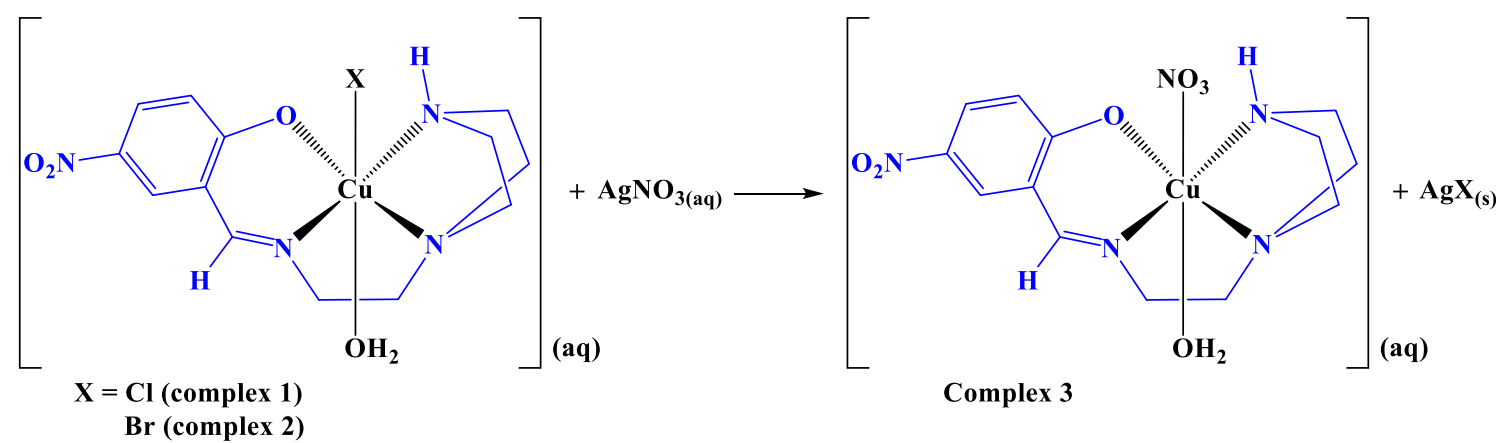

Scheme 2 Gravimetric analysis of complexes $\mathbf{1}$ and $\mathbf{2}$

The magnetic susceptibility of $4 \times 10^{-5} \mathrm{~mol}$ of desired complexes dissolved in 5-mL distilled water was evaluated. At 22 ${ }^{\circ} \mathrm{C}$, the direct magnetic susceptibility was found to be 120 for complex $\mathbf{1}, 110$ for complex $\mathbf{2}$, and 100 for complex $\mathbf{3}$. The magnetic behavior has demonstrated very minor changes with increasing temperature from 22 to $100^{\circ} \mathrm{C}$ as seen (for complex 1) in Fig. 6d.

\subsection{Chromotropism study}

The $\mathrm{d}-\mathrm{d}$ transition of metal ions, metal-to-ligand charge transfers (MLCT) and ligand-to-metal charge transfers (LMCT), are in principle the causes of various good-looking colors in transition metal complexes. However, under chemical or physical conditions, namely chromotropism, the color of some complexes is reversibly altered according to the conditions, which includes electro-redox (electrochromism), ion (ionochromism), light (photochromism), $\mathrm{pH}$ (halochromism), pressure (piezochromism), solvent (solvatochromism), and temperature (thermochromism) reactions [34,35].

The $\mathrm{Cu}(\mathrm{II})$ complexes with $\mathrm{d}^{9}$ electron configuration are expected to possess explicit Jahn-Teller effect, making them attractive targets for solvatochromic investigation. The selected complex 1 was found to have low solubility in organic solvents. For that reason, the number of solvents introduced to the solvatochromism study was limited to water, methanol, DMSO, and DMF. Different colors have been reflected by dissolving the complex in these solvents, visible to the naked eye. In water, the LMCT showed maxima at $355 \mathrm{~nm}$, shifted to $362 \mathrm{~nm}$ in methanol, $373 \mathrm{~nm}$ in DMF, and $375 \mathrm{~nm}$ in DMSO (Fig. 7a). Similarly, the d-d transition absorptions displayed $\lambda_{\max }$ at $658 \mathrm{~nm}$ in water, which shifted to $680 \mathrm{~nm}$ in methanol, $685 \mathrm{~nm}$ in DMF, and $705 \mathrm{~nm}$ in DMSO (Fig. 7b). This phenomenon implies that both bands, LMCT and d-d transition, have the same solvatochromic behavior [36-38]. The solvation relation was examined between the observed maxima of both bands and Gutmann's solvent acceptor
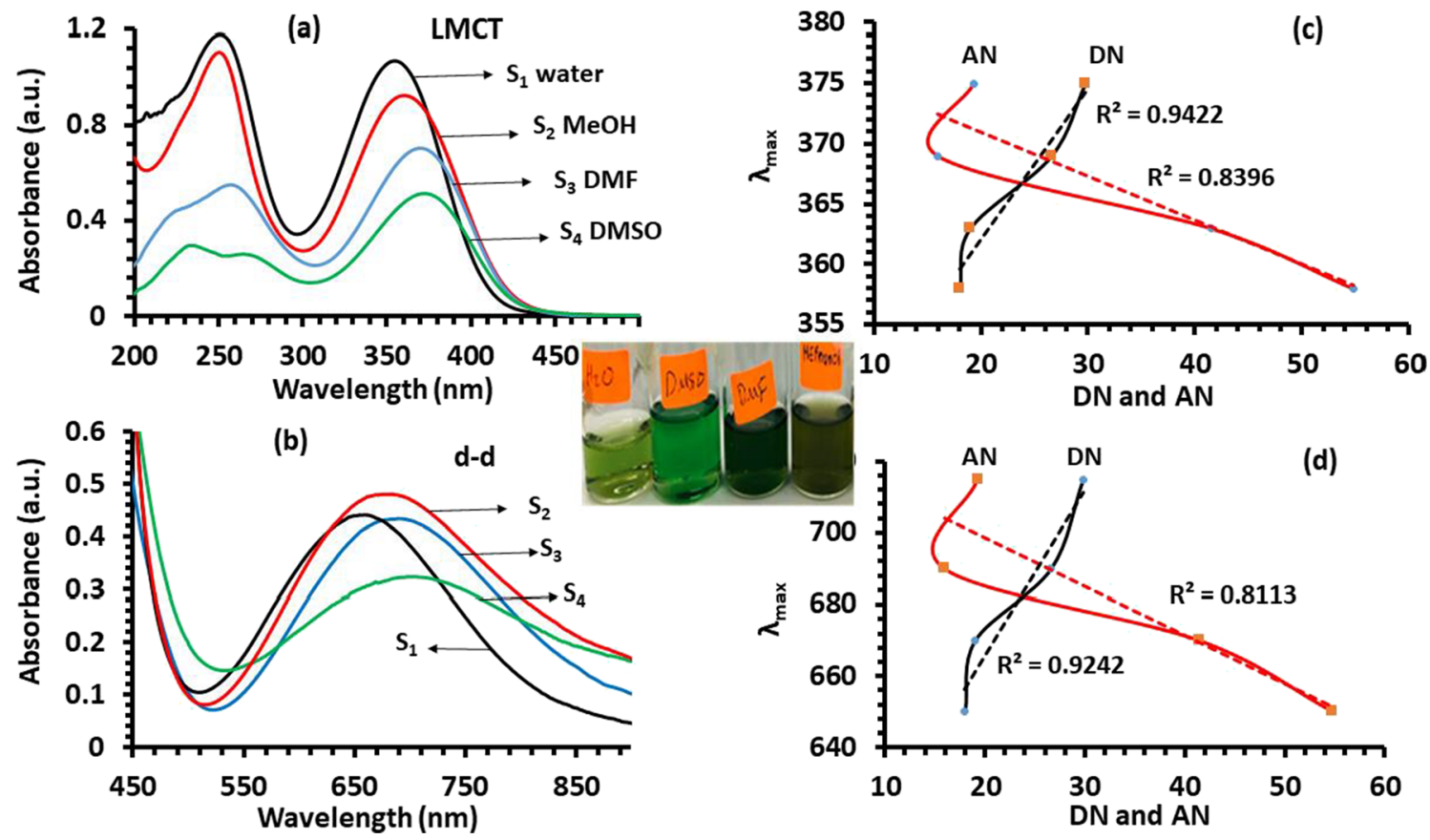

Fig. 7 Solvatochromism of complex 2: Abs vs $\lambda_{\max }$ at LMCT (a) and at d-d (b), $\lambda_{\max }$ vs solvents AN/DN at LMCT (c) and at d-d (d) 


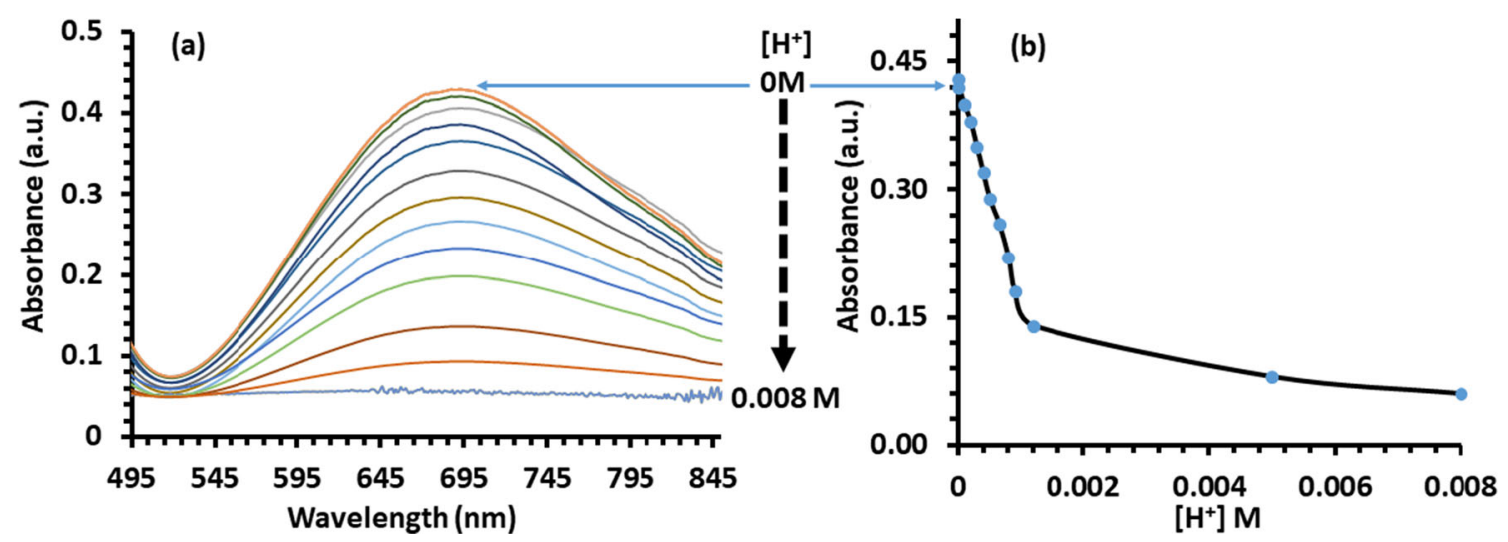

Fig. $8\left[\mathrm{H}^{+}\right]$-dependent visible spectra of the complex 1 in water at RT (a) and Abs vs $\left[\mathrm{H}^{+}\right]$relation at constant $\lambda_{\max }$ (b)

numbers (AN) [39], revealing no clear relation (decreased followed by increased). However, a positive linear relation with Gutmann's solvent donor numbers was displayed with correlation factors $\left(R^{2}\right)$ of 0.942 (LMCT) and 0.924 (d-d transition) as shown in Fig. 7c, d. This behavior indicates that the copper(II) complex is acting as a strong Lewis acid.

The halochromic effect of complex $\mathbf{1}$ was demonstrated as an off-on process. The green-colored solution in DMF was turned to colorless (off) upon the addition of acid-like $\mathrm{HCl}$. Subsequently, the initial color was restored reversibly (on) by addition of basic solution such as $\mathrm{NaOH}$. It was noticed that when the concentration of the added acid increased, the $\lambda_{\max }$ at $670 \mathrm{~nm}$ started to gradually decrease in terms of intensity without visible shifting of the $\mathrm{d}-\mathrm{d}$ band, as shown in Fig. 8a. Hence, the de-colorization of the green solution could be rationalized to the protonation of the coordinated ligand that in turn is responsible for the de-structuring process. The spectrophotometric titration of the complex 1 with $\mathrm{HCl}$ at $\lambda_{\max }=$ $670 \mathrm{~nm}$ showed that the de-colorization is mainly completed after consumption of four equivalent protons (Fig. 8b). Such value is consisted with the tetradentate NNNO protonation nature of the ligand to finish up with hydrated $\mathrm{CuCl}_{2}$ species and expected protonated ligand, ligand (Fig. 8b).
Furthermore, the thermochromic behavior for complex 3 was studied at a temperature range between 20 to $90^{\circ} \mathrm{C}$ with the focus on the $\mathrm{d}-\mathrm{d}$ transition band. A gradual change in color from green to brown has been recorded upon raising up the temperature of the solution of the complex. This could be attributed to the fact that the coordinated halide/nitrate could be dissociated from the metal center and replaced by watersolvent, as seen in Fig. 9a. Therefore, the environmental coordination around the $\mathrm{Cu}(\mathrm{II})$ is changed reflecting a nonlinear bathochromic shift from $615 \mathrm{~nm}$ at $20^{\circ} \mathrm{C}$ to $675 \mathrm{~nm}$ at $90{ }^{\circ} \mathrm{C}$ (Fig. 9b). The thermochromism here is a reversible process since the initial green color returns back after cooling, indicating recovery of the complex [35].

\subsection{Thermogravimetric analysis}

The material purity and thermal stability of the free SB ligand and complex 1 were investigated via thermal gravimetric analysis (TGA) and differential thermal analysis (DTA) in the range of 20 to $900{ }^{\circ} \mathrm{C}$ and heating rate of $10{ }^{\circ} \mathrm{C}$ per minute in an open-atmosphere (Fig. 10). The SB ligand reflected an acceptable stability up to $200{ }^{\circ} \mathrm{C}$, then started to completely decay in a single step with $T_{\text {off }} \sim 450{ }^{\circ} \mathrm{C}$ and $T_{\text {DTA }}=270{ }^{\circ} \mathrm{C}$.
Fig. 9 Complex 3 aqua thermochromism: Abs vs wavelength at different temperatures, and $\lambda_{\max }$ vs temperature relations (b)
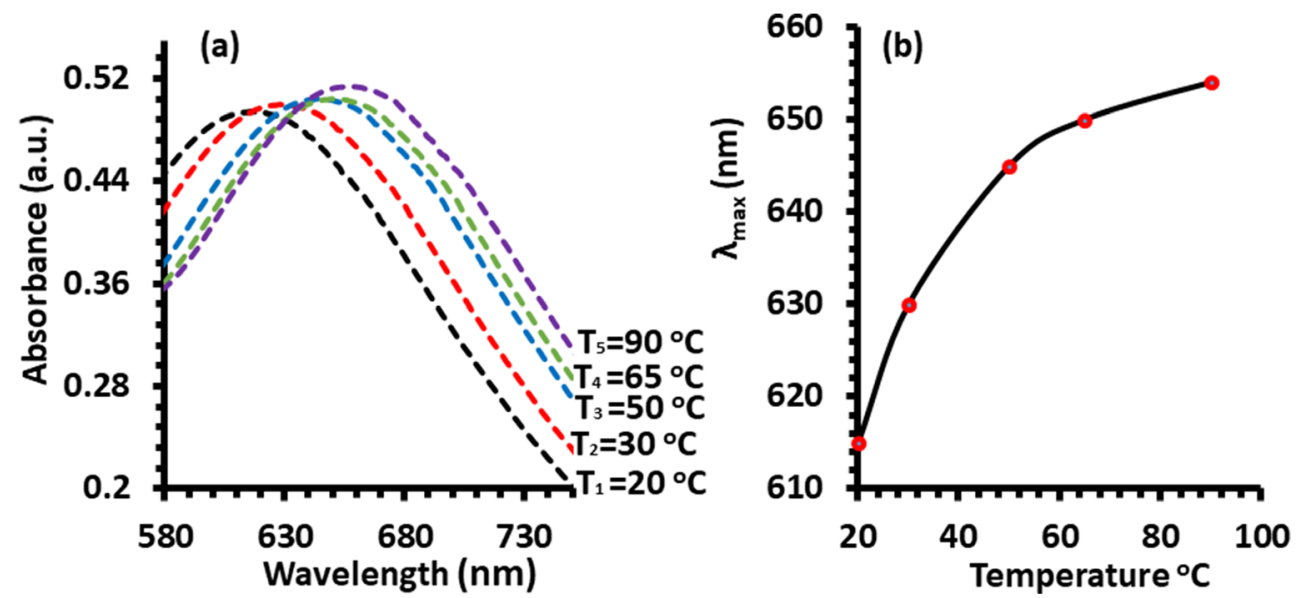


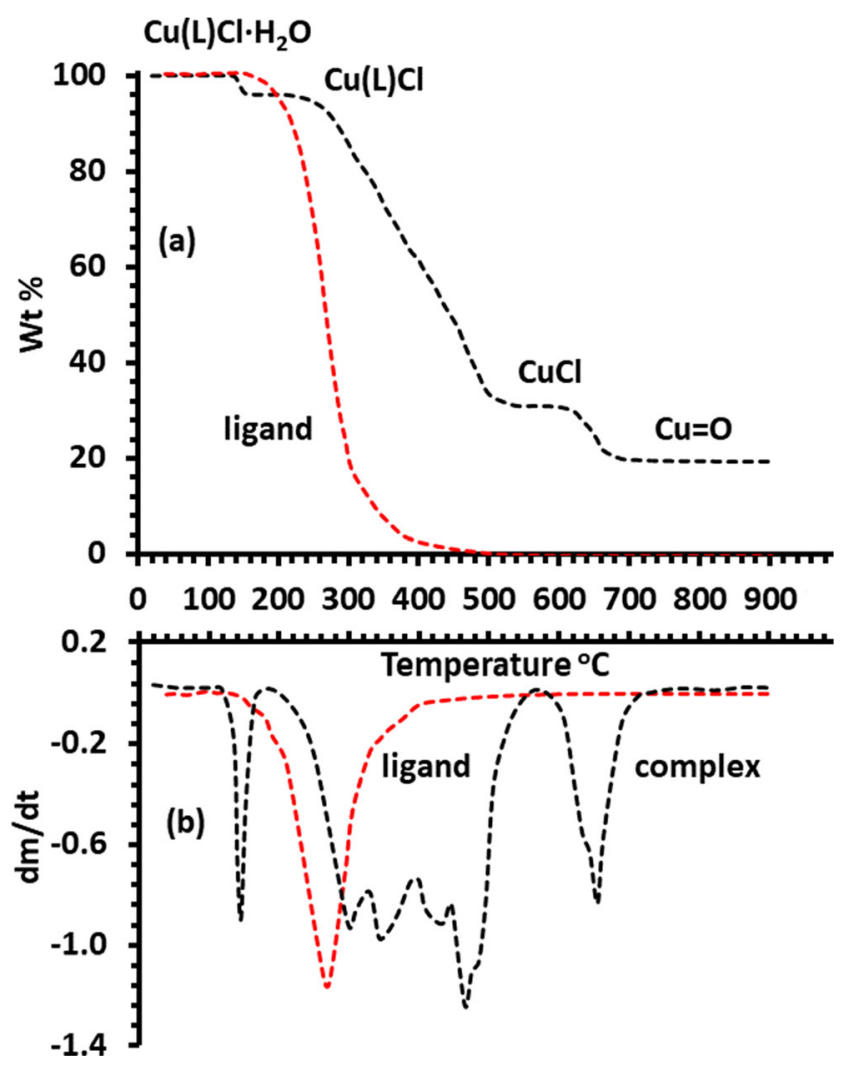

Fig. 10 TGA (a) and DTG (b) of the free SB and complex 1

However, complex 1 showed a completely different decomposition pattern with three successive pyrolysis steps. The first stage of decomposition was recorded between 138 and $155^{\circ} \mathrm{C}$ for the loss of the coordinated water molecule from $\mathrm{Cu}(\mathrm{L}) \mathrm{Cl}$ $\mathrm{H}_{2} \mathrm{O}$ structure with $T_{\text {DTA }}=148{ }^{\circ} \mathrm{C}$. This loss is equivalent to $4.5 \%$ mass (theoretically $4.7 \%$ ) to produce $\mathrm{Cu}(\mathrm{L}) \mathrm{Cl}$ complex. The second step started from 280 to $500{ }^{\circ} \mathrm{C}$ involving approximately $71 \%$ mass loss (theoretically $70.5 \%$ ) for the dissociation of the ligand from the former copper complex residue in a very broad complex step, finished with four $T_{\mathrm{DTA}}=295,340$, $430,470{ }^{\circ} \mathrm{C}$. Finally, the residual $\mathrm{CuCl}$ decomposed to give $\mathrm{Cl}$ and $\mathrm{Cu}$, the later reacted with oxygen to produce $\mathrm{Cu}=\mathrm{O}$ as final remaining, having $T_{\mathrm{DTA}}=650{ }^{\circ} \mathrm{C}$ with $18.8 \%$ yield (theoretically $19.1 \%$ ).

\subsection{Selective catalytic oxidation}

The capability of the three complexes towards selective catalytic oxidation of benzyl alcohol to benzaldehyde has been evaluated using hydrogen peroxide as a green oxidant. The conversion rate, product selectivity, and benzaldehyde yield of the model reaction are demonstrated in Table 1. Typically, a mixture of $2.5 \mathrm{mmol}$ of benzyl alcohol and $5 \mathrm{mmol}$ of $30 \%$ hydrogen peroxide in the presence of $1 \mathrm{~mol} \%$ of copper catalyst in $10 \mathrm{~mL}$ of solvent was heated at $50{ }^{\circ} \mathrm{C}$ for $24 \mathrm{~h}$ in a 20-mL vial.

At a temperature of $50{ }^{\circ} \mathrm{C}$, all copper complexes displayed excellent selectivity, but with variable conversion rate to yield the desired aldehyde without the formation of the unwanted benzoic acid (entries 1-3). When the temperature was raised to $70{ }^{\circ} \mathrm{C}$ or the time was extended to $48 \mathrm{~h}$ (entries 4 and 5), the conversion of benzyl alcohol was accomplished to deliver the product in a moderate yield along with benzoic acid, thermodynamically favored product. Other polar organic solvents, such as THF, MeCN, and DMSO, have demonstrated high percentage of conversion of the starting material (entries 68). Moreover, the reaction did not proceed in the absence of copper catalyst (entry 9) and only traces of the product were detected when no hydrogen peroxide was used (entry 10). Overall, complex 1 was demonstrated as the most active precatalyst at the abovementioned optimized conditions (as seen in Fig. 11a); the temperature was found to be a key factor to control the selectivity of the catalyst. It was noticed that no oxidation reaction was achieved in the presence of trace
Fig. 11 Conversion \% vs time for the three copper complexes (a) and IR-monitored formation of benzaldehyde (b)

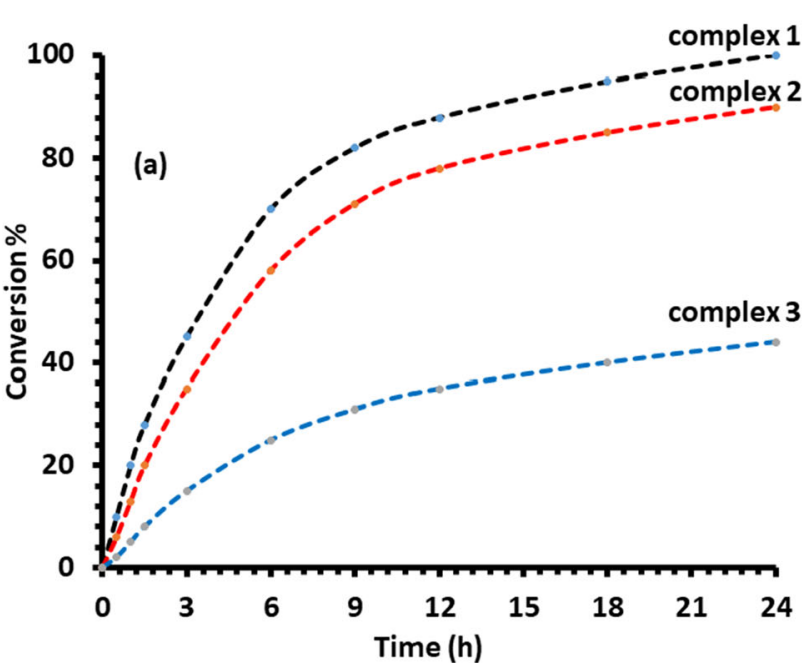

Wavenumber $\left(\mathrm{cm}^{-1}\right)$

$\begin{array}{llll}1770 & 1720 & 1670 & 1620\end{array}$

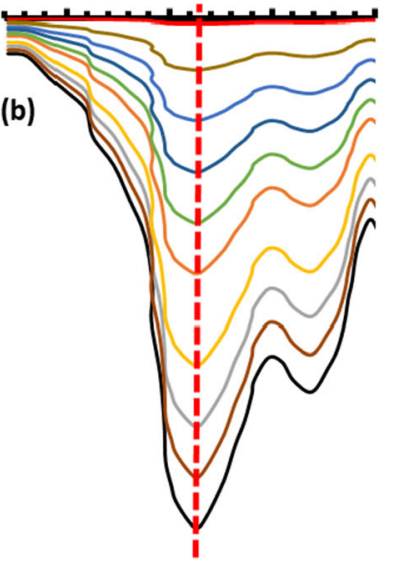

$1705 \mathrm{~cm}^{-1}$ 
amounts of $\mathrm{HCl}$ or $\mathrm{NaOH}$, even after about $50 \%$ of conversion of benzyl alcohol; the addition of acid or base as additive will cease the catalytic reaction. Eventually, to investigate the progress of the reaction, small amounts of samples were taken at appropriate time intervals for direct IR analysis. The concentration of carbonyl functional group of benzaldehyde product was observed to increase by time, as seen in Fig. 11b.

\section{Conclusion}

New NNNOH tetradentate SB-functionalized ligand and its copper(II) complexes were characterized by several spectral analysis. These complexes showed an interesting similar solvatochromic behavior at LMCT and d-d bands, acid-base turn-off-on halochromic effect, and bathochromic thermochromisim behavior. The florescence behavior of the free ligand at $\lambda_{\max }=475 \mathrm{~nm}$ started to turn off by complexation to the copper(II) center as in complex $\mathbf{1}$. The synthesized complexes reflected high degree of catalytic activity in selective oxidation of benzyl alcohol to benzaldehyde using $\mathrm{H}_{2} \mathrm{O}_{2}$ as a green oxidant under mild reaction conditions. Based on the chromotropism and oxidation results, the new $\mathrm{Cu}$ (II) complexes could be utilized as an efficient catalyst in oxidation reactions and material for applications as optical sensors and Lewis acid-base color indicators [34,40].

Acknowledgements The authors gratefully acknowledge the Central Laboratories Unit, Qatar University for accomplishing the analysis.

Author contributions Synthesis and measurement: S. R. A. and R. E. A. under the supervision of I. W. and A. M. S. Characterization, measurements, manuscript preparation, and editing: K. S. M. S., A. M. S., and I. W. All authors have given approval to the final version of the manuscript.

Funding Open access funding provided by the Qatar National Library. K. S. M. S. received the financial support from Qatar University, grant number QUST-1-CAS-2020-4.

\section{Declarations}

Conflict of interest The authors declare no conflict of interest.

Open Access This article is licensed under a Creative Commons Attribution 4.0 International License, which permits use, sharing, adaptation, distribution and reproduction in any medium or format, as long as you give appropriate credit to the original author(s) and the source, provide a link to the Creative Commons licence, and indicate if changes were made. The images or other third party material in this article are included in the article's Creative Commons licence, unless indicated otherwise in a credit line to the material. If material is not included in the article's Creative Commons licence and your intended use is not permitted by statutory regulation or exceeds the permitted use, you will need to obtain permission directly from the copyright holder. To view a copy of this licence, visit http://creativecommons.org/licenses/by/4.0/.

\section{References}

1. H. Schiff, Mittheilungen aus dem Universitätslaboratorium in Pisa: Eine neue Reihe organischer Basen. Justus Liebigs Ann. Chem. 131, 118-119 (1864). https://doi.org/10.1002/jlac.18641310113

2. W. Al Zoubi, A.A.S. Al-Hamdani, M. Kaseem, Synthesis and antioxidant activities of Schiff bases and their complexes: a review. Appl. Organomet. Chem. 30, 810-817 (2016). https://doi.org/10. 1002/aoc.3506

3. M.S. More, P.G. Joshi, Y.K. Mishra, P.K. Khanna, Metal complexes driven from Schiff bases and semicarbazones for biomedical and allied applications: a review. Mater. Today Chem. 14, 100195 (2019). https://doi.org/10.1016/j.mtchem.2019.100195

4. P.G. Lacroix, Second-order optical nonlinearities in coordination chemistry: the case of bis(salicylaldiminato)metal Schiff base complexes. Eur. J. Inorg. Chem. 2001, 339-348 (2001). https://doi.org/ 10.1002/1099-0682(200102)2001:2<339::Aid-ejic339>3.0.Co;2-z

5. I. Badran, L. Abdallah, R. Mubarakeh, I. Warad, Effect of alkyl derivation on the chemical and antibacterial properties of newly synthesized Cu(II)-diamine complexes. Mor. J. Chem. 7, 161-170 (2019)

6. S. Uzun, Z. Demircioğlu, M. Taşdoğan, E. Ağar, Quantum chemical and X-ray diffraction studies of (E)-3-(( $(3,4-$ dimethoxybenzyl)imino)methyl)benzene-1,2-diol. J. Mol. Struct. 1206, 127749 (2020). https://doi.org/10.1016/j.molstruc.2020. 127749

7. M. Ziółek, J. Kubicki, A. Maciejewski, R. Naskręcki, A. Grabowska, An ultrafast excited state intramolecular proton transfer (ESPIT) and photochromism of salicylideneaniline (SA) and its "double" analogue salicylaldehyde azine (SAA). A controversial case. Phys. Chem. Chem. Phys. 6, $4682-4689$ (2004). https://doi. org $/ 10.1039 / \mathrm{b} 406898 \mathrm{j}$

8. J. Jankowska, M.F. Rode, J. Sadlej, A.L. Sobolewski, Excited-state intramolecular proton transfer: photoswitching in salicylidene methylamine derivatives. ChemPhysChem 15, 1643-1652 (2014). https://doi.org/10.1002/cphc.201301205

9. T.M. Krygowski, K. Woźniak, R. Anulewicz, D. Pawlak, W. Kolodziejski, E. Grech, A. Szady, Through-resonance assisted ionic hydrogen bonding in 5-nitro-N-salicylideneethylamine. J. Phys. Chem. A 101, 9399-9404 (1997). https://doi.org/10.1021/ jp970814a

10. L. Antonov, W.M.F. Fabian, D. Nedeltcheva, F.S. Kamounah, Tautomerism of 2-hydroxynaphthaldehyde Schiff bases. J. Chem. Soc. Perkin Trans. 2, 1173-1179 (2000). https://doi.org/10.1039/ b000798f

11. M.R. Aouad, M. Messali, N. Rezki, N. Al-Zaqri, I. Warad, Single proton intramigration in novel 4-phenyl-3-((4-phenyl-1H-1,2,3triazol-1-yl)methyl)-1H-1,2,4-triazole-5(4H)-thione: XRD-crystal interactions, physicochemical, thermal, Hirshfeld surface, DFT realization of thiol/thione tautomerism. J. Mol. Liq. 264, 621-630 (2018). https://doi.org/10.1016/j.molliq.2018.05.085

12. M.R. Aouad, M. Messali, N. Rezki, M.A. Said, D. Lentz, L. Zubaydi, I. Warad, Hydrophobic pocket docking, double-proton prototropic tautomerism in contradiction to single-proton transfer in thione $\Leftrightarrow$ thiol Schiff base with triazole-thione moiety: Green synthesis, XRD and DFT-analysis. J. Mol. Struct. 1180, 455-461 (2019). https://doi.org/10.1016/j.molstruc.2018.12.010

13. A. Guerraoui, A. Djedouani, E. Jeanneau, A. Boumaza, A. Alsalme, A. Zarrouk, K.S.M. Salih, I. Warad, Crystal structure and spectral of new hydrazine-pyran-dione derivative: DFT enol $\leftrightarrow$ hydrazone tautomerization via zwitterionic intermediate, hirshfeld analysis and optical activity studies. J. Mol. Struct. 1220, 128728 (2020). https://doi.org/10.1016/j.molstruc.2020. 128728 
14. A. Soroceanu, M. Cazacu, S. Shova, C. Turta, J. Kožíšek, M. Gall, M. Breza, P. Rapta, T.C.O. Mac Leod, A.J.L. Pombeiro, J. Telser, A.A. Dobrov, V.B. Arion, Copper(II) Complexes with Schiff bases containing a disiloxane unit: synthesis, structure, bonding features and catalytic activity for aerobic oxidation of benzyl alcohol. Eur. J. Inorg. Chem. 2013, 1458-1474 (2013). https://doi.org/10.1002/ ejic. 201201080

15. P. Roy, M. Manassero, Tetranuclear copper(II)-Schiff-base complexes as active catalysts for oxidation of cyclohexane and toluene. Dalton Trans. 39, 1539-1545 (2010). https://doi.org/10.1039/ b914017d

16. S. Hazra, B.G.M. Rocha, M.F.C. Guedes da Silva, A. Karmakar, A.J.L. Pombeiro, Syntheses, structures, and catalytic hydrocarbon oxidation properties of N-heterocycle-sulfonated Schiff base copper(II) complexes. Inorganics 7, 17 (2019). https://doi.org/10. 3390/inorganics 7020017

17. T.F.S. Silva, L. Martins, Recent advances in copper catalyzed alcohol oxidation in homogeneous medium. Molecules 25, 748 (2020). https://doi.org/10.3390/molecules25030748

18. A. Dutta, M. Chetia, A.A. Ali, A. Bordoloi, P.S. Gehlot, A. Kumar, D. Sarma, Copper nanoparticles immobilized on nanocellulose: a novel and efficient heterogeneous catalyst for controlled and selective oxidation of sulfides and alcohols. Catal. Lett. 149, 141-150 (2018). https://doi.org/10.1007/s10562-018-2615-x

19. J.U. Ahmad, M.T. Räisänen, M. Leskelä, T. Repo, Copper catalyzed oxidation of benzylic alcohols in water with $\mathrm{H}_{2} \mathrm{O}_{2}$. Appl. Catal. A Gen. 411-412, 180-187 (2012). https://doi.org/10.1016/j. apcata.2011.10.038

20. Albonetti, S.; Mazzoni, R.; Cavani, F. CHAPTER 1 Homogeneous, heterogeneous and nanocatalysis. In Transition Metal Catalysis in Aerobic Alcohol Oxidation, The Royal Society of Chemistry: 2015; https://doi.org/10.1039/9781782621652-00001. pp. 1-39.

21. T. Mallat, A. Baiker, Oxidation of alcohols with molecular oxygen on platinum metal catalysts in aqueous solutions. Catal. Today 19, 247-283 (1994). https://doi.org/10.1016/0920-5861(94)80187-8

22. M. Musawir, P.N. Davey, G. Kelly, I.V. Kozhevnikov, Highly efficient liquid-phase oxidation of primary alcohols to aldehydes with oxygen catalysed by Ru-Co oxide. Chem. Commun. 2003, 1414-1415 (2003). https://doi.org/10.1039/b212585b

23. E.J. Baran, Structural data and vibrational spectra of the copper(II) complex of L-selenomethionine. Z. Naturforsch. 60b, 663-666 (2005). https://doi.org/10.1515/znb-2005-0609

24. R. Mathammal, K. Sangeetha, M. Sangeetha, R. Mekala, S. Gadheeja, Molecular structure, vibrational, UV, NMR, HOMOLUMO, MEP, NLO, NBO analysis of 3,5 di tert butyl 4 hydroxy benzoic acid. J. Mol. Struct. 1120, 1-14 (2016). https://doi.org/10. 1016/j.molstruc.2016.05.008

25. M.A. Said, H.A. Qasem, S.O. Alzahrani, A. Zarrouk, I. Warad, Synthesis and XRD of neutral NiL complex using unsymmetrical ONNO tetradentate schiff base: Hirschfeld, spectral, DFT and thermal analysis. J. Coord. Chem. 73, 1280-1291 (2020). https://doi. org $/ 10.1080 / 00958972.2020 .1762870$

26. R.M. Silverstein, G.C. Bassler, T.C. Morrill, Spectrometric identification of organic compounds, 5th edn. (Wiley, New York, 1991). https://doi.org/10.1002/oms.1210260923

27. I. Badran, S. Tighadouini, S. Radi, A. Zarrouk, I. Warad, Experimental and first-principles study of a new hydrazine derivative for DSSC applications. J. Mol. Struct. 1229, 129799 (2021). https://doi.org/10.1016/j.molstruc.2020.129799

28. N. Al-Zaqri, K.S.M. Salih, F.F. Awwadi, A. Alsalme, F.A. Alharthi, A. Alsyahi, A.A. Ali, A. Zarrouk, M. Aljohani, A.
Chetouni, et al., Synthesis, physicochemical, thermal, and XRD/ HSA interactions of mixed $[\mathrm{Cu}(\mathrm{Bipy})(\mathrm{Dipn})](\mathrm{X})_{2}$ complexes: DNA binding and molecular docking evaluation. J. Coord. Chem. 73, 3236-3248 (2020). https://doi.org/10.1080/00958972. 2020.1841898

29. Z.A. Li, X. Lou, H. Yu, Z. Li, J. Qin, An Imidazole-functionalized polyfluorene derivative as sensitive fluorescent probe for metal ions and cyanide. Macromolecules 41, 7433-7439 (2008). https://doi. org/10.1021/ma8013096

30. H. Ando, K. Tawa, M. Tanaka, Fluorescence and metal-ion recognition properties of acetylacetone-based ligands. J. Environ. Sci. 21, S84-S87 (2009). https://doi.org/10.1016/s1001-0742(09)60044-9

31. S. Demir, B. Eren, M. Hołyńska, (1-Methyl-2-(thiophen-2-yl)-1Hbenzo[d]imidazole) and its three copper complexes: synthesis, characterization and fluorescence properties. J. Mol. Struct. 1081, 304 310 (2015). https://doi.org/10.1016/j.molstruc.2014.10.043

32. E. Şenkuytu, M. Bingul, M.F. Saglam, H. Kandemir, I.F. Sengul, Synthesis of a novel N, $\mathrm{N}^{\prime}, \mathrm{N}^{\prime}$-tetraacetyl-4,6-dimethoxyindolebased dual chemosensor for the recognition of $\mathrm{Fe}^{3+}$ and $\mathrm{Cu}^{2+}$ ions. Inorg. Chim. Acta 495, 118947 (2019). https://doi.org/10.1016/j. ica.2019.05.046

33. G.J. Kharadi, Effect of substituent of terpyridines on the in vitro antioxidant, antitubercular, biocidal and fluorescence studies of copper(II) complexes with clioquinol. Spectrochim. Acta A Mol. Biomol. Spectrosc. 117, 662-668 (2014). https://doi.org/10.1016/ j.saa.2013.09.049

34. Fukuda, Y. Inorganic chromotropism: basic concepts and applications of colored materials; Springer: 2007.

35. H. Golchoubian, G. Moayyedi, N. Reisi, Halochromism, ionochromism, solvatochromism and density functional study of a synthesized copper(II) complex containing hemilabile amide derivative ligand. Spectrochim. Acta A Mol. Biomol. Spectrosc. 138, 913-924 (2015). https://doi.org/10.1016/j.saa.2014.10.027

36. M.K. Hema, C.S. Karthik, N.K. Lokanath, P. Mallu, A. Zarrouk, K.S.M. Salih, I. Warad, Synthesis of novel Cubane $\left[\mathrm{Ni}_{4}(\mathrm{O} \cap \mathrm{O})_{4}\left(\mathrm{OCH}_{3}\right)_{4}(\mathrm{OOH})_{4}\right]$ cluster: XRD/HSA-interactions, spectral, DNA-binding, docking and subsequent thermolysis to NiO nanocrystals. J. Mol. Liq. 315, 113756 (2020). https://doi. org/10.1016/j.molliq.2020.113756

37. I. Warad, S. Musameh, I. Badran, N.N. Nassar, P. Brandao, C.J. Tavares, A. Barakat, Synthesis, solvatochromism and crystal structure of trans- $\left[\mathrm{Cu}\left(\mathrm{Et}_{2} \mathrm{NCHCH}_{2} \mathrm{NH}_{2}\right)_{2} \cdot \mathrm{H}_{2} \mathrm{O}\right]\left(\mathrm{NO}_{3}\right)_{2}$ complex: experimental with DFT combination. J. Mol. Struct. 1148, 328-338 (2017). https://doi.org/10.1016/j.molstruc.2017.07.067

38. I. Warad, F.F. Awwadi, B. Abd Al-Ghani, A. Sawafta, N. Shivalingegowda, N.K. Lokanath, M.S. Mubarak, T. Ben Hadda, A. Zarrouk, F. Al-Rimawi, et al., Ultrasound-assisted synthesis of two novel $\left.[\mathrm{CuBr} \text { (diamine })_{2} \cdot \mathrm{H}_{2} \mathrm{O}\right] \mathrm{Br}$ complexes: solvatochromism, crystal structure, physicochemical, Hirshfeld surface thermal, DNA/binding, antitumor and antibacterial activities. Ultrason. Sonochem. 48, 1-10 (2018). https://doi.org/10.1016/j.ultsonch. 2018.05.009

39. U. Mayer, V. Gutmann, W. Gerger, The acceptor number ? A quantitative empirical parameter for the electrophilic properties of solvents. Monatsh. Chem. 106, 1235-1257 (1975). https://doi.org/ $10.1007 / \mathrm{bf00913599}$

40. J.L. Meinershagen, T. Bein, Solvatochromism of a Copper(II) (tetramethylethylenediamine)-(acetylacetonate) ${ }^{+}$complex encapsulated in EMT zeolite cages. Adv. Mater. 13, 208-211 (2001). https://doi.org/10.1002/1521-4095(200102)13:3<208::AIDADMA208>3.0.CO;2-U 